\title{
Epidemiology of Patients with Super-Refractory Schizophrenia
}

\author{
Irena Thoma ${ }^{1}$, Anastas Suli ${ }^{2}$ \\ Psychiatric Service, University Hospital Centre "Mother Theresa" Tirana, Albania
}

\begin{abstract}
Schizophrenia and first-episode psychosis are disorders with considerable heterogeneity in several of its basic features. The aim of the study was to give an epidemiological overview of patients with super refractory schizophrenia.The patients included in this study were those participating in a prospectively designed clozapine monitoring program (n=102 subjects) who completed at least 52 weeks of treatment and had complete data records at Psychiatric Hospital, University Hospital Centre "Mother Theresa" in Tirana, Albania over the period $2013-2014$. In the study participated 102 subjects with a mean age $44.2( \pm 10.7)$ years with a range 22-74 years old.Thirty five (34.3\%) were women and 67 (65.7\%) men meeting both DSM-IV criteria for schizophrenia and Kane's criteria for drugresistance.93 (61.2\%) of patient were form urban areas while only 9 (9.8\%) of them lived in rural area. The majority of patients 62 (60.8\%) are single, and 46 (45.1\%) of them had only 8 years of school and $48 \%$ of them have a low and very low economic status.Schizophrenia usually persists, continuously or episodically, for a lifetime. Complete remission off antipsychotic medication is uncommon.
\end{abstract}

Keywords: schizophrenia, super refractory, epidemiology, gender differences

\section{Introduction}

Schizophrenia and first-episode psychosis are disorders with considerable heterogeneity in several of its basic features. There is great variability in clinical presentation, disease course, and response to both pharmacological and psychosocial treatment (1).Some aspects of this heterogeneity may be gender related and, given the reliability, stability, and validity of its definition, study of the gender variable may help explain the differences. Gender differences have been studied extensively in recent decades and although there are definite findings, much uncertainty remains about the extent of the differences (2). This paper will try to summarize the most relevant research done around the world on gender differences in schizophrenia and first-psychosis episodes. The topics discussed in this paper will be prevalence and incidence, age of onset, symptoms, premorbid, social and cognitive functioning, substance abuse, course of illness, physical health and metabolic complications, and familial risk and obstetric complications (3). The paper will try to assess gender differences studies on each of these topics in people with schizophrenia and in first-episode psychosis. A greater understanding of the gender differences presents in schizophrenia and firstepisode psychosis can help us design more effective preventive and intervention actions (4).The existence of gender differences in the incidence of schizophrenia has been subject to debate. Traditionally, it was accepted that the incidence and prevalence of schizophrenia was the same in men and women however, recent studies suggest gender differences in the incidence of the illness. Lewine et al. (5) were the first to note that by using more restrictive criteria for the diagnosis of schizophrenia, the number of women excluded from the definition is greater than men. Castle et al. (6) applied a different set of diagnostic criteria to an incidence sample of patients with a wide range of nonaffective psychosis presentations and found that the effect of different diagnostic criteria on the gender ratio is profound. For example, the Feighner restrictive criteria found a ratio of female-men $0.41: 1$ and the ICD the ratio female-men is $0.92: 1$. Using standard diagnostic criteria in an incidence population study, a meta-analysis by Aleman et al. (7) confirmed that the men had a higher incidence (ratio 1.42). However, the recent studies of prevalence of schizophrenia in general population did not find gender differences $(8,9)$. One possible explanation for the disparity between incidence and prevalence could be related to compliance with treatment and higher rates of suicide completion in men than in women (10). Another possible explanation could be related to the design of the studies, for example, one centered more in epidemiological resources and the incidence was centered in clinical data. Gender differences have been found in prevalence of schizophrenia in epidemiological studies; however, it seems that more new cases of schizophrenia have been detected in men. The aim of the study was to give an epidemiological overview of patients with super refractory schizophrenia.

\section{Material and Methods}

The patients included in this study were those participating in a prospectively designed clozapine monitoring program (n $=102$ subjects) who completed at least 52 weeks of treatment and had complete data records at Psychiatric Hospital, University Hospital Centre "Mother Theresa" in Tirana, Albania over the period 2013 -2014. In an effort to have consistent baseline conditions, before entering into the study, all the patients' psychoactive drugs except for typical antipsychotics were tapered and discontinued. After patients had been taken on this drug regimen for at least 2 weeks, baseline assessment was completed. Then, clozapine treatment was started with dose increments of $25-50 \mathrm{mg}$ every 2 days to bring patients to the dose of $400 \mathrm{mg} /$ day by the end of the week 2. Patients were taken at this dose regimen up to the end of week 4 , when a second clinical assessment was performed. Those subjects meeting the response criteria (see below) were maintained on the 400 $\mathrm{mg} /$ day dose regimen up to the end of the study, whereas the remaining patients received further dose increments of 50 $\mathrm{mg}$ every 2 days to reach the maximum established dose of 


\section{International Journal of Science and Research (IJSR) \\ ISSN (Online): 2319-7064 \\ Index Copernicus Value (2013): 6.14 | Impact Factor (2014): 5.611}

$600 \mathrm{mg} /$ day by the end of week 6 , and then were kept on this dose regimen up to week 52. Typical antipsychotics were rapidly tapered and discontinued during the first week of clozapine treatment. Clozapine was administered in 2-3 divided (and approximately equal) doses, with the last dose of the day given between 7:00 P.M. and 8:00 P.M. Patients were hospitalized up to the achievement of their maximum clozapine daily dose; then, they were discharged and clozapine was administered at home by staff nurses, who carefully checked patients' compliance up to the end of the study. Psychopathological assessment was performed by means of the Expanded Brief Psychiatric Rating Scale (BPRS: 24 items and a scoring from 1 to 7 ) both before starting clozapine (baseline) and every 2 weeks up to week 52. Patients were a priori defined responders as they attained a $20 \%$ decrease in the BPRS total score plus a post-treatment BPRS score of 47 or less. These criteria had to be met at two consecutive rating points; responders were classified as such when they first met a priori criteria.

\section{Results and Discussion}

In the study participated 102 subjects with a mean age 44.2 $( \pm 10.7)$ years with a range $22-74$ years old.Thirty five $(34.3 \%)$ were women and $67(65.7 \%)$ men meeting both DSM-IV criteria for schizophrenia The mean duration of their illness was 23.4 years.93 $(61.2 \%)$ of patient were form urban areas while only $9(9.8 \%)$ of them lived in rural area. The majority of patients $62(60.8 \%)$ are single, and 46 $(45.1 \%)$ of them had only 8 years of school and $48 \%$ of them have a low and very low economic status. The most affected agegroup is $41-50$ years old with 37 (36.3\%) Of the 102patients, $27(26.8 \%)$ were classified as responders, 45 (44\%) being refractory (Clozapine responders) and 30 $(29.2 \%)$ super-refractory. The super-refractory group had the highest scores for totals of BPRS $(p<0.01)$ in all visits. To date, only a few studies have addressed the characteristics of patients with super-refractory schizophrenia.There are numerous gender differences in the presentation and course of schizophrenia $(10,11)$. Men with schizophrenia have been noted to have a younger age at onset, a poorer premorbidhistory, more negative symptoms, a greater likelihood of having the deficit syndrome $(12,13)$, and a poorer overall course than women with schizophrenia (14). Compared withmen, women are more likely to have affective symptoms, auditory hallucinations, and persecutorydelusions, but they have a better overall course and better outcomes than men, as evidencedby better social and occupational functioning, fewer hospitalizations, and less substance use andantisocial behavior (15). While such differences may be biologically mediated, psychosocialfactors, including family and societal expectations, may also affect outcome. Haas andcolleagues (16) noted that social and occupational role demands may result in unrealistic familyexpectations of men with schizophrenia, and this issue should be dealt with in treatment.There are also gender differences in both response to and adverse effects of treatments forschizophrenia. Most of this research has been conducted with first-generation antipsychotic medications.Women exhibit more rapid responses to antipsychotic medications and a greater degreeof improvement in both first-episode and multiepisode schizophrenia (17). It has also been observedthat even after body weight is considered, women require lower antipsychotic doses (18) than men, although there is suggestive evidence that postmenopausal women may requirehigher doses. Although women may show greater responsivity to antipsychotics, they alsoexperience more neurological side effects, including acute dystonia, parkinsonism, akathisia, andtardive dyskinesia (19). Women also develop higher serum prolactin levels in response to bothfirst-generation antipsychotics and risperidone, compared with men (20), and therefore womenmay be more prone to the sexual side effects of the medications. Finally, although studies of gender differences in response to psychosocial treatments are sparse, there is some evidence to suggest that social skills training may be more effective for male patients, whereas inpatient family interventions have shown greater success in families of female patients (21).

\section{Conclusion}

Schizophrenia usually starts between the late teens and the mid-30s, whereas onset prior to adolescence is rare (although cases with age at onset of 5 or 6 years have been reported). Schizophrenia can also begin later in life, after age 45 years, but this is uncommon. Usually the onset of Schizophrenia occurs a few years earlier in men than women. The onset may be abrupt or insidious. Usually Schizophrenia starts gradually with a prepsychotic phase of increasing negative symptoms. A few months or years later, a psychotic phase develops. Individuals who have an onset of Schizophrenia later in their 20's or 30's are more often female, have less evidence of structural brain abnormalities or cognitive impairment, and display a better outcome. Schizophrenia usually persists, continuously or episodically, for a lifetime. Complete remission off antipsychotic medication is uncommon. Yet $10 \%-20 \%$ of individuals with Schizophrenia fully recover on antipsychotic medication. Some individuals appear to have a relatively stable course, whereas others show a progressive worsening associated with severe disability. The psychotic symptoms usually respond to treatment with antipsychotic medication, whereas the negative symptoms are less responsive to antipsychotic medication. Often the negative symptoms steadily become more prominent during the course of Schizophrenia.

\section{References}

[1] A. Aleman, R. S. Kahn, and J. P. Selten, "Sex differences in the risk of schizophrenia: evidence from meta-analysis," Archives of General Psychiatry, vol. 60, no. 6, pp. 565-571, 2003. View at Publisher ·View at Google Scholar · View at Scopus

[2] J. Perälä, J. Suvisaari, S. I. Saarni et al., "Lifetime prevalence of psychotic and bipolar I disorders in a general population," Archives of General Psychiatry, vol. 64, no. 1, pp. 19-28, 2007. View at Publisher - View at Google Scholar · View at Scopus

[3] J. McGrath, S. Saha, D. Chant, and J. Welham, "Schizophrenia: a concise overview of incidence, prevalence, and mortality," Epidemiologic Reviews, vol. 30, no. 1, pp. 67-76, 2008. View at Publisher -View at Google Scholar · View at Scopus 


\section{International Journal of Science and Research (IJSR) \\ ISSN (Online): 2319-7064}

Index Copernicus Value (2013): 6.14 | Impact Factor (2014): 5.611

[4] American Psychiatric Association: Practice guideline for the treatment of patients with schizophrenia, second edition. Am J Psychiatry 2004; 161(Feb Suppl)

[5] S. Ochoa, J. Usall, V. Villalta-Gil et al., "Influence of age at onset on social functioning in outpatients with schizophrenia," European Journal of Psychiatry, vol. 20, no. 3, pp. 157-163, 2006. View at Google Scholar View at Scopus

[6] Mouaffak F, Tranulis C, Gourevitch R, Poirier MF, Douki S, Olié JP, Lôo H, Gourion D: Augmentation strategies of clozapine with antipsychotics in the treatment of ultraresistant schizophrenia. ClinNeuropharmacol 2006; 29:28-33

[7] Sernyak MJ, Rosenheck RA: Antipsychotic use in the treatment of outpatients with schizophrenia in the VA from fiscal years 1999 to 2006. PsychiatrServ 2008; 59:567-569

[8] V. A. Morgan, D. J. Castle, and A. V. Jablensky, "Do women express and experience psychosis differently from men? Epidemiological evidence from the Australian National Study of Low Prevalence (Psychotic) Disorders," Australian and New Zealand Journal of Psychiatry, vol. 42, no. 1, pp. 74-82, 2008. View at Publisher - View at Google Scholar - View at Scopus

[9] Perkins DO, Gu H, Boteva K, Lieberman JA: Relationship between duration of untreated psychosis and outcome in firstepisode schizophrenia: a critical review and meta-analysis. Am JPsychiatry 2005; 162:1785-1804

[10] Agid O, Arenovich T, Sajeev G, Zipursky RB, Kapur S, Foussias G, Remington G: An algorithm-based approach to first-episode schizophrenia: response rates over 3 prospective antipsychotic trials with a retrospective data analysis. J Clin Psychiatry 2011; 72: 1439-1444

[11]Derks EM, Fleischhacker WW, Boter H, Peuskens J, Kahn RS; EUFEST Study Group: Antipsychotic drug treatment in first-episode psychosis: should patients be switched to a different antipsychotic drug after 2, 4, or 6 weeks of nonresponse? J Clin Psychopharmacol2010; 30:176-180

[12] Emsley R, Oosthuizen PP, Kidd M, Koen L, Niehaus DJ, Turner HJ: Remission in first-episode psychosis: predictor variables and symptom improvement patterns. J Clin Psychiatry 2006; 67:1707-1712

[13] Emsley R, Rabinowitz J, Medori R: Time course for antipsychotic treatment response in first-episode schizophrenia. Am J Psychiatry 2006; 163:743-745

[14] Schennach-Wolff R, Seemüller FH, Mayr A, Maier W, Klingberg S, Heuser I, Klosterkötter J, Gastpar M, Häfner H, Sauer H, Schneider F, Gaebel W, Jäger M, Möller HJ, Riedel M: An early improvement threshold to predict response and remission in first-episode schizophrenia. Br J Psychiatry 2010; 196:460-466

[15] Stauffer VL, Case M, Kinon BJ, Conley R, AscherSvanum H, Kollack-Walker S, Kane J, McEvoy J, Lieberman J: Early response to antipsychotic therapy as a clinical marker of subsequent response in the treatment of patients with first-episode psychosis. Psychiatry Res 2011; 187:42-48

[16] Girgis RR, Phillips MR, Li X, Li K, Jiang H, Wu C, Duan N, Niu Y, Lieberman JA: Clozapine v. chlorpromazine in treatment-naive,first-episode schizophrenia: 9-year outcomes of a randomized clinical trial. Br J Psychiatry 2011; 199:281-288

[17] Rosenheck RA, Davis S, Covell N, Essock S, Swartz M, Stroup S, McEvoy J, Lieberman J: Does switching to a new antipsychotic improve outcomes? Data from the CATIE Trial. Schizophr Res 2009; 107:22-29

[18] Howes OD, Vergunst F, Gee S, McGuire P, Kapur S, Taylor D: Adherence to treatment guidelines in clinical practice: study of antipsychotic treatment prior to clozapine initiation. Br J Psychiatry 2012, 201(6):481485.

[19] S. M. Cotton, M. Lambert, B. G. Schimmelmann et al., "Gender differences in premorbid, entry, treatment, and outcome characteristics in a treated epidemiological sample of 661 patients with first episode psychosis," Schizophrenia Research, vol. 114, no. 1-3, pp. 17-24, 2009. View at Publisher.

[20] A. Barajas, I. Baños, S. Ochoa et al., "Age of onset of a first psychotic episode: are there any clinical differences between men and women?" PsiquiatriaBiologica, vol. 14, no. 4, pp. 136-141, 2007. View at Google Scholar View at Scopus

[21] Gallego JA, Bonetti J, Zhang J, Kane JM, Correll CU: Prevalence and correlates of antipsychotic polypharmacy: a systematic review and meta-regression of global and regional trends from the 1970s to 2009 . Schizophr Res 2012, 138(1):18-28.

Table 1: Sociodemographic characteristics of patients

\begin{tabular}{|c|c|c|c|}
\hline Variables & $\mathbf{N}$ & $\%$ & $\mathbf{P}$ \\
\hline Gender & & & 0.5 \\
\hline Females & 35 & 34.3 & \\
\hline Males & 67 & 65.7 & \\
\hline Agegroup, yrs & & & $<0.01$ \\
\hline$\leq 30$ & 13 & 12.7 & \\
\hline $31-40$ & 28 & 27.5 & \\
\hline $41-50$ & 37 & 36.3 & \\
\hline $51-60$ & 16 & 15.7 & \\
\hline$>60$ & 8 & 7.8 & \\
\hline Residence & & & $<0.01$ \\
\hline Urban & 93 & 91.2 & \\
\hline Rural & 9 & 9.8 & \\
\hline CivilStatus & & & $<0.01$ \\
\hline Single & 62 & 60.8 & \\
\hline Married & 22 & 21.6 & \\
\hline Divorced & 18 & 17.6 & \\
\hline Education level & & & $<0.01$ \\
\hline None & 3 & 2.9 & \\
\hline 4 years & 10 & 9.8 & \\
\hline 8 years & 46 & 45.1 & \\
\hline High school & 32 & 31.4 & \\
\hline University & 9 & 8.8 & \\
\hline Post university & 1 & 1.0 & \\
\hline Socio-economic status & & & $<0.01$ \\
\hline Very low & 24 & 23.5 & \\
\hline Low & 25 & 24.5 & \\
\hline Moderate & 53 & 52.0 & \\
\hline
\end{tabular}

